\title{
A resin-buffered nutrient solution for controlling metal speciation in the algal bottle assay
}

L. Verheyen", R. Merckx and E. Smolders

Division of Soil and Water Management, Department Earth and Environmental Sciences, K.U.Leuven, Kasteelpark Arenberg 20 - box 2459, 3001 Heverlee, Belgium.

*Corresponding author: Tel.: +32 16321630 , fax: +32 16321997

E-mail address: Liesbeth.Verheyen@ees.kuleuven.be 


\section{Abstract}

Metal speciation in solution is uncontrolled during algal growth in the traditional algal bottle assay. A resin-buffered nutrient solution was developed to overcome this problem and this was applied to test the effect of chloride $\left(\mathrm{Cl}^{-}\right)$on cadmium $(\mathrm{Cd})$ uptake. Standard nutrient solution was enriched with $40 \mathrm{mM}$ of either $\mathrm{NaNO}_{3}$ or $\mathrm{NaCl}$, and was prepared to contain equal $\mathrm{Cd}^{2+}$ but varying dissolved $\mathrm{Cd}$ due to the presence of $\mathrm{CdCl}_{\mathrm{n}}{ }^{2-\mathrm{n}}$ complexes. Both solutions were subsequently used in an algal assay in $100 \mathrm{~mL}$ beakers that contained only the solution (designated "-R") or contained the solution together with a cation exchange sulphonate resin $\left(2 \mathrm{~g} \mathrm{~L}^{-1}\right.$, designated "+R") as a deposit on the bottom of the beaker. Pseudokirchneriella subcapitata was grown for $72 \mathrm{~h}\left(1.4 \times 10^{5}-1.4 \times 10^{6}\right.$ cells $\left.\mathrm{mL}^{-1}\right)$ in stagnant solution and shaken three times a day. Growth was unaffected by the presence of the resin ( $p>0.05)$. The Cd concentrations in solution of the $-\mathrm{R}$ devices decreased with $50-58 \%$ of initial values due to $\mathrm{Cd}$ uptake. No such changes were found in the $+\mathrm{R}$ devices or in abiotic controls. Cd uptake was unaffected by either $\mathrm{NaNO}_{3}$ or $\mathrm{NaCl}$ treatment in the $+\mathrm{R}$ device, confirming that $\mathrm{Cd}^{2+}$ is the preferred $\mathrm{Cd}$ species in line with the general concept of metal bioavailability. In contrast, $\mathrm{Cd}$ uptake in the $-\mathrm{R}$ devices was two-fold larger in the $\mathrm{NaCl}$ treatment than in the $\mathrm{NaNO}_{3}$ treatment $(\mathrm{p}<0.001)$, suggesting that $\mathrm{CdCl}_{\mathrm{n}}{ }^{2-\mathrm{n}}$ complexes are bioavailable in this traditional set-up, however this bioavailability is partially, but not completely, an apparent one, because of the considerable depletion of solution ${ }^{109} \mathrm{Cd}$ in this set-up. Resin-buffered solutions are advocated in the algal bottle assay to control trace metal supply and to better identify the role of metal complexes on bioavailability.

Keywords: Metal uptake - Cadmium - Metal buffering - Metal selective-resin - Green Algae 


\section{Introduction}

Algal toxicity tests have been conducted since the beginning of the $20^{\text {th }}$ century. A standard methodology did not exist until the algal assay bottle test was designed by United States Environmental Protection Agency in 1971 (EPA-600/9-78-018, 1978). This method was modified in 1978 and is nowadays used as the standard method (Calow, 1998). Standard tests for screening toxicity of contaminants to algae are traditionally based on batch systems, commonly denoted as algal bottle tests. Algae are grown at modest cell densities in flasks without replacement of solution and growth is related to initial or final solution composition. For testing effects of metals, it is recommended to exclude metal chelators from the nutrient solution to avoid metal complexation which affects metal bioavailability (EPA-600/9-78-018, 1978; OECD 201, 2006). However, in the absence of a metal chelating agent, the free metal ion activity in solution is not buffered and hence is subject to change due to algal uptake and/or due to complexation reactions by algal exudates. This means that the standard method has inherent limitations for metals in the absence of measured metal speciation data. Speciation can be measured, e.g. with electrochemical methods or with Donnan dialysis, however such methods are time consuming and often have their limitations when applied at low (background) concentrations (Sigg et al., 2006).

In plant nutrition studies, the chelator-buffered nutrient solution system has been developed as a research tool to supply and buffer trace metals at low, but environmentally relevant concentrations (Parker et al., 1995). The diagnostics of deficient to adequate metal ion activities in solution then critically rely on the accuracy of the calculated metal speciation and on the assumption that complexes do not contribute to uptake, i.e. they rely on the Free Ion activity Model (FIAM) for uptake. The FIAM was shown to hold for metal toxicity to algae (Anderson et al., 1978) and was confirmed in numerous subsequent studies (Allen et al., 1980; Vigneault and Campbell, 2005). However, a few exceptions to the FIAM have been 
reported for metal uptake by algae. Fortin and Campbell (2000) found that uptake of Ag by a unicellular alga at fixed $\mathrm{Ag}^{+}$activity increased as the concentration of chloride $\left(\mathrm{Cl}^{-}\right)$, which forms $\mathrm{AgCl}^{\circ}$ complexes, increased. Lamelas et al. (2009) observed a higher $\mathrm{Pb}$ internalization flux in the presence of $10 \mathrm{mg} \mathrm{L}^{-1}$ humic acids than in the presence of $3 \times 10^{-4} \mathrm{M}$ citric acid at identical free $\mathrm{Pb}^{2+}$ concentrations. Some exceptions to the FIAM involve low molecular weight metabolites as citrate (Errecalde et al., 1998) or lipophilic complexes (Florence and Stauber, 1986; Phinney and Bruland, 1994), suggesting that the contribution of the complex was due to direct uptake of the complex.

Checkai et al. (1987) developed a resin-buffered solution as an alternative for the chelator-buffered method in plant nutrition research. Cation exchange resins can buffer free ion activities in solution with varying concentrations of metal complexing ligands (Holm et al. 1995). Since resins are physically separated from the plants, the FIAM can be more sensitively tested with the resin method compared to chelator-buffered systems. Using this technique, it was shown that metal uptake in plants increased with increasing concentrations of ligands, either added ligands or plant derived ligands (Smolders and McLaughlin,1996; Degryse et al., 2007). The contributions of the labile metal complexes to plant uptake have been related to their capacity to buffer the free ion in local depletion zones around active roots. Such depletion zones should be less prevalent with suspended microalgae since the diffusive (unmixed) zone can be assumed to be much smaller than around roots (Wilkinson \& Buffle, 2004).

As far as we know, no resin-buffered system has yet been set up for algae. The advantage of this system is that the resin maintains the ion activity by (i) replenishing the metal ion after algal uptake and/or (ii) counteracting metal complexing reactions from algal exudates. The objective of this study was to develop and test the resin-buffered system for static algal cultures. Specific attention was given to test effects of the resin on growth and on the kinetics 
of ion buffering. Two resins were compared, i.e. Chelex resin (chelating resin, high specificity for trace metals) and the Amberlite resin (cation exchange resin, low specificity for trace metals). The new system was applied to test the effects of chloride on Cd uptake and was compared to a conventional, unbuffered system.

\section{Materials and Methods}

\subsection{Metal buffering kinetics in the growth devices}

The algal bottle test is often used in stagnant (not agitated) solution, excluding some hand-shaking (2-3 times per day, depending on the procedures). The kinetics of metal release from the resin to the solutions were verified in a stagnant set up without using algae. Resin loaded with $\mathrm{Cd}$ was transferred to solution not containing $\mathrm{Cd}$ and the $\mathrm{Cd}$ desorption kinetics were monitored under conditions similar to those of biotic systems. To prepare the Cd-loaded resin, the sodium form of the cation exchange resin Amberlite-CG120 (Rohm \& Haas comp., 4.4 mmol charge ( $\mathrm{g}$ wet weight $)^{-1}$ ) and Chelex-100 (Bio-rad, sodium form, 0.62 mmol charge $(\mathrm{g} \text { wet weight })^{-1}$ ) were exchanged with $\mathrm{Ca} / \mathrm{Mg}$ using $200 \mathrm{~mL}$ of $500 \mathrm{mM} \mathrm{Ca}\left(\mathrm{NO}_{3}\right)_{2}$ and 25 $\mathrm{mM} \mathrm{MgCl} 2$. The Ca and $\mathrm{Mg}$ loaded resins were filtered and rinsed with $200 \mathrm{~mL}$ milli-Q water and with $100 \mathrm{~mL}$ test medium containing $5 \mathrm{mM}$ MES (pH 6), $5 \mathrm{mM} \mathrm{Ca}\left(\mathrm{NO}_{3}\right)_{2}, 20 \mu \mathrm{M}$ $\mathrm{K}_{2} \mathrm{HPO}_{4}, 0.25 \mathrm{mM} \mathrm{MgSO}$ and $0.1 \mathrm{mM} \mathrm{K}_{2} \mathrm{SO}_{4}$. Six g of rinsed Amberlite and $0.06 \mathrm{~g}$ of rinsed Chelex was exchanged with radiolabelled ${ }^{109} \mathrm{Cd}\left(6.6 \mathrm{kBq} \mathrm{g}^{-1}\right.$ Amberlite, $46 \mathrm{MBq} \mathrm{g}^{-1}$ Chelex $)$ in $100 \mathrm{~mL}$ test medium for 3 days in an end over end shaker $(20 \mathrm{rpm})$. The test medium was removed and the resin was transferred to $100 \mathrm{~mL}$ beakers, i.e. about $2 \mathrm{~g}$ of Amberlite or about $0.02 \mathrm{~g}$ of Chelex. Fresh test medium $(30 \mathrm{~mL})$ not containing radiolabelled ${ }^{109} \mathrm{Cd}$ was added to the beakers. The test medium was sampled at regular intervals before and after the addition of 
new solution without stirring the suspension. The ${ }^{109} \mathrm{Cd}$ activity concentration in solution was monitored by a gamma counter (Packard Instruments COBRA Auto-Gamma 5003).

\subsection{Test organism}

A stock culture of Pseudokirchneriella supcapitata (Korschikov) Hindák 1990. was obtained from the Culture Collection of Algae and Protozoa (CCAP 278/4, Windermere, UK). Upon arrival, the algae were transferred to $50 \mathrm{~mL}$ sterilized culture medium in $200 \mathrm{~mL}$ Erlenmeyer flasks. The culture medium is an adjusted WC-medium and contains $0.25 \mathrm{mM}$ $\mathrm{CaCl}_{2}, 0.15 \mathrm{mM} \mathrm{MgSO}_{4}, 0.15 \mathrm{mM} \mathrm{NaHCO}_{3}, 65.4 \mu \mathrm{M} \mathrm{K}_{2} \mathrm{HPO}_{4}, 0.5 \mathrm{mM} \mathrm{NH} \mathrm{NO}_{3}, 5 \mathrm{mM}$ HEPES (pH 7.4), $13 \mu \mathrm{M} \mathrm{Na}{ }_{4} E D T A, 11.7 \mu \mathrm{M} \mathrm{FeCl}_{3}, 40 \mathrm{nM} \mathrm{CuCl} 2,76.5 \mathrm{nM} \mathrm{ZnSO}, 42 \mathrm{nM}$ $\mathrm{CoCl}_{2}, 0.91 \mu \mathrm{M} \mathrm{MnCl}_{2}, 23.4 \mathrm{nM} \mathrm{Na}_{2} \mathrm{MoO}_{4}$, and 16.2 $\mu \mathrm{M} \mathrm{H}_{3} \mathrm{BO}_{3}$. The Erlenmeyer flasks were autoclaved for 20 minutes. After initiating the culture (cell density between $10^{4}$ and $10^{5}$ cells $\mathrm{mL}^{-1}$ ), the flasks were closed with a cotton stopper. Every 7 days, cells were diluted in fresh medium to a cell density between $10^{4}$ and $10^{5}$ cells $\mathrm{mL}^{-1}$. The algae were grown under a $12 \mathrm{~h} / 12 \mathrm{~h}$ day/night cycle with illumination of $90 \mu \mathrm{E} \mathrm{m}^{-2} \mathrm{~s}^{-1}$ (cool white fluorescent lamps) and constant temperature of $21 \pm 1^{\circ} \mathrm{C}$. The cultures were continuously shaken with a horizontal shaker. Only algae in the exponential growth phase were used for the uptake experiments for which growth conditions were different compared to the culture conditions (see below).

\subsection{Preparation of the resins}

Amberlite resin was exchanged with $\mathrm{Ca}^{2+}, \mathrm{Mg}^{2+}$ and $\mathrm{Na}^{+}$before exposure to the algae, to obtain a composition in equilibrium with that in the exposure medium for the algae. The molar ratio of $\mathrm{Na} / \mathrm{Ca} / \mathrm{Mg}$ in the exposure medium is $42.5 / 1 / 0.25$. The high $\mathrm{Na}$ concentration is atypical for natural waters but is a result of the addition of chloride as the Na salt. The resins were exchanged in advance at high salt concentrations, thereby accounting the heterovalence effect i.e. the ratio of solution $\mathrm{Na}^{+}$(molar units) to the square root of solution $\mathrm{Ca}^{2+}+\mathrm{Mg}^{2+}$ in 
solution equals that of the exposure medium. About $250 \mathrm{~mL}$ of $950 \mathrm{mM} \mathrm{NaCl}, 125 \mathrm{mM}$ $\mathrm{MgCl}_{2}$ and $500 \mathrm{mM} \mathrm{Ca}\left(\mathrm{NO}_{3}\right)_{2}$ was equilibrated with $30 \mathrm{~g}$ resin for $1 \mathrm{~h}$, separated by filtration and rinsed with milli-Q and $200 \mathrm{~mL}$ exposure medium (see below) containing $40 \mathrm{mM} \mathrm{NaNO}$ and no radiolabelled ${ }^{109} \mathrm{Cd}$. For test media with different compositions, typically with smaller $\mathrm{Na} / \mathrm{Ca}$ ratios, this resin exchange solution should logically be adjusted.

\subsection{Cadmium uptake experiment}

The algal bottle test was applied to test the effect of $\mathrm{NaCl}$ versus $\mathrm{NaNO}_{3}$ on Cd uptake by algae in the presence $(+\mathrm{R})$ or in the absence $(-\mathrm{R})$ of the Amberlite resin. The exposure medium contained $5 \mathrm{mM}$ MOPS (3-morpholinopropane-1-sulfonic acid, adjusted to $\mathrm{pH} 7.4$ with about $2.5 \mathrm{mM} \mathrm{NaOH}), 1 \mathrm{mM} \mathrm{Ca}\left(\mathrm{NO}_{3}\right)_{2}, 20 \mu \mathrm{M} \mathrm{K}_{2} \mathrm{HPO}_{4}, 0.25 \mathrm{mM} \mathrm{MgSO}_{4}, 0.6 \mathrm{mM}$ $\mathrm{NaHCO}_{3}, 0.1 \mathrm{mM} \mathrm{K}_{2} \mathrm{SO}_{4}, 15 \mu \mathrm{M}$ FeHBED (Iron N,N9-di-(2-hydroxybenzoyl)ethylenediamine-N,N9-diacetic acid), $0.3 \mu \mathrm{M} \mathrm{MnCl}_{2}, 3 \mu \mathrm{M} \mathrm{H}_{3} \mathrm{BO}_{3}, 30 \mathrm{nM} \mathrm{Na}_{2} \mathrm{MoO}_{4}, 62 \mathrm{nM}$ $\mathrm{CoCl}_{2}, 100 \mathrm{nM} \mathrm{ZnCl}, 100 \mathrm{nM} \mathrm{CuCl}$, trace levels of ${ }^{109} \mathrm{Cd}\left(80 \mathrm{kBq}{ }^{109} \mathrm{Cd} \mathrm{L}^{-1}\right)$ and either 40 $\mathrm{mM} \mathrm{NaNO}_{3}$ or $\mathrm{NaCl}$. The FeHBED was prepared with excess $\mathrm{Fe}^{3+}$ as described before to avoid any free chelator in solution (Chaney, 1988). The specific activity of the ${ }^{109} \mathrm{Cd}$ spike was not given by the supplier but is typically $>100 \mathrm{kBq} \mathrm{\mu g}^{-1} \mathrm{Cd}$ in previous spikes used in our group. The equilibrium ${ }^{109} \mathrm{Cd}$ activity in solutions here $\left(5-10 \mathrm{kBq} \mathrm{L}^{-1}\right.$; Table 1$)$ is then equivalent to $0.05-0.1 \mu \mathrm{g} \mathrm{Cd} \mathrm{L}{ }^{-1}$ or about $0.5-1 \mathrm{nM} \mathrm{Cd}$ in solution, i.e. trace level $\mathrm{Cd}$ at which uptake and sorption are all proportional to solution concentrations (Vigneault and Campbell, 2005). Indeed, measured Cd in solution was undetectable ( $<20 \mathrm{nM})$ by inductively coupled plasma/optical emission spectroscopy (ICP-OES, Perkin-Elmer Optima 3300 DV, Norwalk, CT, USA). In the $\mathrm{NaNO}_{3}$ medium, complexation of $\mathrm{Cd}$ is negligible (4\%) as predicted by GEOCHEM-PC (Parker et al., 1995). In the $\mathrm{NaCl}$ medium, 33\% Cd in solution is present as a free ion, the remainder mainly as $\mathrm{CdCl}^{+}$. The solutions of both the $+\mathrm{R}$ and $-\mathrm{R}$ were identical and were first prepared by equilibrating these with the resin. Six gram of the resin prepared as 
described above (55\% moisture content) was added to $200 \mathrm{~mL}$ exposure medium, either with $40 \mathrm{mM} \mathrm{NaCl}$ or $40 \mathrm{mM} \mathrm{NaNO}_{3}$. The resin suspension was equilibrated by end over end shaking for 3 days. The solution was sampled after equilibration and before starting the uptake experiments and analysed by ICP-OES and, for ${ }^{109} \mathrm{Cd}$, with the gamma-counter.

Half of the $200 \mathrm{~mL}$ exposure solution was used for the $-\mathrm{R}$ treatments, the other part for the $+\mathrm{R}$ treatments. There were three replicates for each treatment. The test was performed in $100 \mathrm{~mL}$ beakers containing $30 \mathrm{~mL}$ of uptake solution. The $6 \mathrm{~g}$ resin was evenly divided among the three $+\mathrm{R}$ replicates. To inoculate, the algae from stock cultures were centrifuged (4500g, $15 \mathrm{~min}$ ), and rinsed three times with a solution containing $5 \mathrm{mM} \mathrm{CaCl}_{2}, 3 \mu \mathrm{M} \mathrm{H}_{3} \mathrm{BO}_{3}$ and $5 \mathrm{mM}$ HEPES (pH 7.4). The resuspended cells were inoculated into the uptake solutions at an initial cell density of $1.5 \times 10^{5}$ cells $\mathrm{mL}^{-1}$ (counted with particle counter HIAC Royco 9705). The beakers were covered with parafilm to minimize the evaporation, but were not totally closed to allow gas exchange. The experiment was performed in a growth chamber with a constant temperature of $21^{\circ} \mathrm{C} \pm 1^{\circ} \mathrm{C}$. Solutions (+R) without algae (abiotic) were included as controls and set up alongside the biotic ones.

All experiments were carried out under continuous illumination of $90 \mu \mathrm{E} \mathrm{m}^{-2} \mathrm{~s}^{-1}$ (cool white fluorescent lamps). The beakers were shaken three times a day. One $\mathrm{mL}$ of uptake solution was sampled and its activity concentration was assayed. Every $24 \mathrm{~h}$, solution ${ }^{109} \mathrm{Cd}$ activity was measured after sampling a homogeneous uptake solution $(1 \mathrm{~mL})$. The sample was centrifuged $(4500 \mathrm{~g}, 15 \mathrm{~min}$ ) and $0.8 \mathrm{~mL}$ of the supernatant was assayed. The $\mathrm{pH}$ of the exposure medium was controlled during the test and adjusted if needed. After three days, 10 $\mathrm{mL}$ of the homogeneous solution with algae and without resin was sampled. The resin beads were separated from the homogeneous solution with algae by natural sedimentation. The sedimentation of the resin beads is much faster than that of the algae because of the larger diameter $(0.5-1 \mathrm{~mm})$ of the beads than that of the algae $(2-3 \mu \mathrm{m})$. The solution with algae was 
centrifuged (4500g, $15 \mathrm{~min}$ ) and $1 \mathrm{~mL}$ of the supernatant was assayed. The rest of the supernatant was removed and the algae were rinsed with a wash solution $(5 \mathrm{~mL})$ containing 1 mM Na${ }_{4}$ EDTA and $5 \mathrm{mM}$ MOPS (pH 7.4) to remove adsorbed ${ }^{109} \mathrm{Cd}$. This washing procedure was verified using short-term ${ }^{109} \mathrm{Cd}$ influx analysis. The ${ }^{109} \mathrm{Cd}$ taken up by the algae was determined after centrifugation and removal of the wash solution and resuspension of the cells in $1 \mathrm{~mL}$ milli-Q.

The cell density in the beakers was determined daily. The growth rate of the algae was calculated from the initial cell density $\left(Q_{\text {ini }}\right)$ and the cell density $\left(Q_{\text {fin }}\right)$ at the end of the assay (time $t$ ) as:

$$
\mu=\ln \left(Q_{\text {fin }} / Q_{\text {ini }}\right) / t
$$

\section{Results}

\subsection{Metal buffering kinetics in the growth devices}

Upon solution renewal, solution ${ }^{109} \mathrm{Cd}$ activity concentrations were readily restored to initial values through ${ }^{109} \mathrm{Cd}$ release from the resin at the bottom of the beaker (Figure 1). The release kinetics of solution ${ }^{109} \mathrm{Cd}$ (in $\mathrm{cpm} / \mathrm{mL}$ ) were fitted to a first order model, i.e. ${ }^{109} \mathrm{Cd}=$ ${ }^{109} \mathrm{Cd}_{\mathrm{eq}} \times(1-\mathrm{exp}(-\mathrm{k} \times \mathrm{t}))$ with ${ }^{109} \mathrm{Cd}_{\mathrm{eq}}$ the solution ${ }^{109} \mathrm{Cd}$ at equilibrium and $\mathrm{k}$, a rate constant

$\left(\mathrm{h}^{-1}\right)$. Rate constants were $0.47 \mathrm{~h}^{-1}$ (Amberlite) and $0.09 \mathrm{~h}^{-1}$ (Chelex). Interpolation predicts that $75 \%$ of the equilibrium value was reached after less than $3 \mathrm{~h}$ (Amberlite) or $18.5 \mathrm{~h}$ (Chelex).

\subsection{Cd uptake experiments in presence and absence of Amberlite}

A decrease of $\mathrm{Na}$ and increases of $\mathrm{Ca}+\mathrm{Mg}$ in the exposure medium were obtained after resin equilibration compared to the composition of the exposure medium before equilibration 
(Table 1). The concentration of $\mathrm{K}$ decreased after resin equilibration because the resin was not loaded in advance with $\mathrm{K}$. The concentration of $\mathrm{Cu}$ and $\mathrm{Zn}$ after equilibration was below the detection limit of ICP-OES, but could be estimated from the measured solid-liquid distribution of Cd by Amberlite (Table 1) because the selectivity of Amberlite for the metals $\mathrm{Cu}, \mathrm{Zn}$ and $\mathrm{Cd}$ is similar (Demirbas et al., 2005). The ratio of total $\mathrm{Cd}$ on solid to that in solution is 16 at the $2 \mathrm{~g}$ resin to $30 \mathrm{~mL}$ solution ratio in the test beakers. This factor 16 denotes the Cd buffer power of this device. The concentration of stable Cd was below the detection limit $(<20 \mathrm{nM})$ of ICP-OES. This corresponds with the earlier information about the specific activity of ${ }^{109} \mathrm{Cd}$ (see above). Dissolved $\mathrm{Cu}$ concentration was detectable after but not before the three days of culture in the $+\mathrm{R}$ treatment (Table 1) and may reflect the effect of algal exudates that complex and mobilize $\mathrm{Cu}$.

The growth rate of the algae in the $\mathrm{NaCl}$ treatments was not significantly different $(\mathrm{p}>$ 0.05) from that in the corresponding $\mathrm{NaNO}_{3}$ treatments (Figure 2). We observed no significant difference in the growth rate $(p>0.05)$ between the $+R$ and $-R$ treatments of either the $\mathrm{NaCl}$ or $\mathrm{NaNO}_{3}$ treatments (Error! Reference source not found.).

Initial ${ }^{109} \mathrm{Cd}$ concentrations, measured after resin equilibration but prior to algal growth, were about 2.2 fold larger in the $\mathrm{NaCl}$ treatment compared to that of the $\mathrm{NaNO}_{3}$ treatment (Table 2). This is related to the presence of $\mathrm{CdCl}_{n}{ }^{2-n}$ complexes. The predicted initial free $\mathrm{Cd}^{2+}$ ion was similar, but not identical between both treatments (Table 2). The concentration of ${ }^{109} \mathrm{Cd}$ decreased with at least $50 \%$ in all -R treatments during the $72 \mathrm{~h}$ algal growth experiment. In contrast, small but statistically insignificant changes were found for the exposure solution in $+\mathrm{R}$ treatment (Table 2 and Figure 3 ). The ${ }^{109} \mathrm{Cd}$ concentrations in the abiotic solutions (+R) were constant through time. The uptake of ${ }^{109} \mathrm{Cd}$ by algae from the $\mathrm{NaNO}_{3}$ medium in the $-\mathrm{R}$ treatment was over twofold lower than that in the corresponding $+\mathrm{R}$ treatment. The uptake of ${ }^{109} \mathrm{Cd}$ from the $\mathrm{NaNO}_{3}$ medium was $58 \%(-\mathrm{R})$ and $150 \%(+\mathrm{R})$ 
relative to quantity of ${ }^{109} \mathrm{Cd}$ present in the initial solution, i.e. Cd uptake in the presence of the resin was greater than the amount initially present in solution because of continuous replenishment by the resin. Excellent recoveries of the ${ }^{109} \mathrm{Cd}$ in the $-\mathrm{R}$ treatments were obtained, i.e. final solution and algal ${ }^{109} \mathrm{Cd}$ were within $2 \%$ of initial solution ${ }^{109} \mathrm{Cd}$. The ${ }^{109} \mathrm{Cd}$ uptake was about twofold greater for the $\mathrm{NaCl}(-\mathrm{R})$ treatment than for the $\mathrm{NaNO}_{3}(-\mathrm{R})$ treatment, despite the similar initial free $\mathrm{Cd}^{2+}$ activities, an apparent contradiction of the FIAM. In contrast, the ${ }^{109} \mathrm{Cd}$ uptake by the algae in the $\mathrm{NaCl}(+\mathrm{R})$ treatment was not significantly different $(\mathrm{p}>0.05)$ from that in the corresponding $\mathrm{NaNO}_{3}$ treatment in line with the FIAM.

\section{Discussion}

Metal selective resins are widely used in studies with trace metals. Amberlite is mostly used as an extractant to remove metals from solution (Dizge et al., 2009; Panahi et al., 2011). Chelex has been used as a buffer for metals during uptake experiments by plants (Checkai et al., 1987; Smolders and McLaughlin, 1996). Here, we used Amberlite as a source for metals during the uptake experiments with green algae. The buffer kinetics of Amberlite are clearly faster than those of Chelex in this set up (Fig.1). In preliminary experiments, we included Chelex in biotic systems with equal cell densities as in the biotic test with Amberlite and found ${ }^{109} \mathrm{Cd}$ to decrease during uptake, i.e. the replenishment rate was not sufficient to match uptake (details not shown), therefore Amberlite was preferred. The buffer kinetics of Amberlite $\left(\mathrm{k}=0.47 \mathrm{~h}^{-1}\right)$ are based on unstirred systems and are a lower estimate of the kinetics for the static biotic culture which is shaken three times a day. The constant solution $\mathrm{Cd}$ concentration in the $+\mathrm{R}$ treatment, despite a high $\mathrm{Cd}$ uptake, indicates a fast release of $\mathrm{Cd}$ during the exposure experiment. Holm et al. (1995) reported Cd equilibrium between Amberlite and solution within one hour in agitated suspensions. 
The presence of Amberlite during the exposure experiment had no significant effect ( $\mathrm{p}>$ 0.05) on the growth of the algae, but did have an effect on the Cd uptake by the green algae. The higher Cd uptake by the algae in $+\mathrm{R}$ compared to $-\mathrm{R}$ systems is due to the buffering of Cd by Amberlite since Cd uptake is proportional to solution $\mathrm{Cd}^{2+}$ at the low free metal ion activities (Vigneault and Campbell, 2005).

The effect of $\mathrm{NaCl}$ compared to $\mathrm{NaNO}_{3}$ on Cd uptake was strikingly different between $+\mathrm{R}$ and $-\mathrm{R}$. Cd uptake was unaffected by the medium composition in the $+\mathrm{R}$ treatment whereas it was about twice as large in the $\mathrm{NaCl}$ compared to $\mathrm{NaNO}_{3}$ medium in the absence of the resin. Because the initial $\mathrm{Cd}^{2+}$ is similar in both test media, it can be inferred that the FIAM holds in the presence of the resin, but not in its absence. The violation of the FIAM in the absence of the resin suggests that the $\mathrm{CdCl}_{\mathrm{n}}^{2-\mathrm{n}}$ complexes (mainly $\mathrm{CdCl}^{+}$) are bioavailable. This bioavailability is partially, but not completely, an apparent one, because of the considerable depletion of solution ${ }^{109} \mathrm{Cd}$ in this set-up, i.e. the capacity of $\mathrm{CdCl}_{\mathrm{n}}{ }^{2-\mathrm{n}}$ complexes to buffer $\left[\mathrm{Cd}^{2+}\right]$ yields more constant $\mathrm{Cd}^{2+}$ during the test and, hence, higher uptake. However, a quantitative analysis of the data of Table 2 suggests that ${ }^{109} \mathrm{Cd}$ depletion is not the only factor and that the FIAM might also have been violated at marginal solution depletion. If the $\mathrm{Cd}$ uptake is proportional (i.e. first order) to the free ion concentration in solution $\left[\mathrm{Cd}^{2+}\right](\mathrm{mol} \mathrm{L}$ ${ }^{1}$ ) and if the total uptake from solution is proportional to the actual cell density $\mathrm{N}\left(\right.$ cell $\left.\mathrm{L}^{-1}\right)$, then the loss of total dissolved Cd concentration from solution $[\mathrm{Cd}]\left(\mathrm{mol} \mathrm{L}^{-1}\right)$ reads:

$$
\frac{d[C d]}{d t}=-k_{\text {cell }} N\left[C d^{2+}\right]
$$

with $\mathrm{k}_{\text {cell }}$ the cell specific $\mathrm{Cd}$ uptake rate $\left(\mathrm{mol}\right.$ day $^{-1}$ cell $\left.^{-1}\right)$. The free ion concentration is proportional to the dissolved concentration

$$
\left[C d^{2+}\right]=\beta[C d]
$$


with $\beta$ the fraction of free ion in solution ( 0.96 for $\mathrm{NaNO}_{3}$ solution, 0.33 for $\mathrm{NaCl}$ solution). Eqn.(2) assumes instantaneous equilibrium between the metal complex and metal ion. The cell number increases during depletion and exponential growth, with rate constant $r\left(\right.$ day $\left.^{-1}\right)$, is assumed

$$
N=N_{0} e^{r t}
$$

Combining Eqns (2-4) yields the dissolved Cd at time $\mathrm{t}[\mathrm{Cd}]_{\mathrm{t}}$ relative to that at the start $[\mathrm{Cd}]_{0}$ as:

$$
[C d]_{t}=[C d]_{0} e^{\frac{k_{C g I I} \beta\left(N_{t}-N_{0}\right)}{r}}
$$

$\mathrm{N}_{0}$ is the cell density at time 0 and $\mathrm{N}_{\mathrm{t}}$ the cell density at time $\mathrm{t}$. The $[\mathrm{Cd}]_{\mathrm{t}} /[\mathrm{Cd}]_{0}$ is $0.42( \pm 0.01$, standard deviation) in the $\mathrm{NaNO}_{3}$ experiment (Table 2). Growth in the $\mathrm{NaCl}$ solution is almost identical to that of the $\mathrm{NaNO}_{3}$ solution, i.e. $\mathrm{r}$ and $\left(\mathrm{N}_{\mathrm{t}}-\mathrm{N}_{\mathrm{o}}\right)$ are almost identical. Using observed growth data of both solutions, Eqn (4) predicts that the depletion of $\mathrm{Cd}$ (i.e. $[\mathrm{Cd}]_{\mathrm{t}} /[\mathrm{Cd}]_{0}$ ) would be $0.74( \pm 0.02)$ if $\mathrm{k}_{\text {cell }}$ would be equal in $\mathrm{NaCl}$ as in $\mathrm{NaNO}_{3}$ solution in line with the FIAM as in the resin-buffered solutions. However, the observed depletion was significantly more pronounced, i.e. $[\mathrm{Cd}]_{t} /[\mathrm{Cd}]_{0}=0.50( \pm 0.04$; Table 2$)$. This suggest that the $\mathrm{CdCl}_{\mathrm{n}}{ }^{2-\mathrm{n}}$ complexes contributed to uptake. Potentially, the complexes contribute to uptake by overcoming diffusive limitation between solution and cells. Such diffusion limitation is often observed for Cd in metal uptake experiments with plants (Degryse et al., 2007). The algae are mainly located on the bottom of the beaker between stirring events and a depletion of $\mathrm{Cd}^{2+}$ in an unstirred layer adjacent to settled cells might occur where $\mathrm{CdCl}_{\mathrm{n}}{ }^{2-\mathrm{n}}$ complexes dissociate and contribute to bioavailability. In the presence of the resin, algae are associated with the resin that locally maintain solution $\mathrm{Cd}^{2+}$ through which the FIAM is valid.

The equal uptake of $\mathrm{Cd}$ by the algae in the $+\mathrm{R}$ treatments confirm the general concept of metal bioavailability, described by FIAM. The $\mathrm{Cd}^{2+}$ ion seems to be the preferred ion, like 
found in the study of Vigneault and Campbell (2005). In the same work, no contribution of Cd-NTA complexes to the Cd uptake was observed and humic substances influenced the $\mathrm{Cd}$ uptake only by reducing the free $\mathrm{Cd}^{2+}$ concentration.

It is unlikely that the standard algal bottle test will consistently yield different results in the presence of resins compared to the classic set-up as found here. First, validity criteria of the standard algal bottle assay state that solution concentrations of the contaminant remain within $20 \%$ of nominal values. Here, depletions of solution metal were $>50 \%$, which was related to the high initial cell density used $\left(15 \times 10^{4}\right.$ cells $\mathrm{mL}^{-1}$, larger than standard: $5 \times 10^{3}$ $5 \times 10^{4}$ ). Franklin et al. 2002 found that $\mathrm{Cu}$ toxicity (EC50) reduced by factors $2-4$ by increasing initial cell densities between $10^{2}-10^{5}$ cells $\mathrm{mL}^{-1}$ which was related to larger depletion and less $\mathrm{Cu}$ bound to cells. Such suggests that resins may not have such a large effect on metal uptake at lower or conventional initial cell densities. However, we argued above that depletion of $\mathrm{Cd}$ is not the only reason why the FIAM is violated in the absence of the resin. Second, metal depletion under metal toxic conditions is clearly less pronounced than at lower concentrations, i.e. existing metal toxicity studies are not strictly invalidated. However, resin-buffered solutions can be advocated in the algal bottle assay to control trace metal supply, e.g. when ligand concentrations such as natural organic matter cannot be maintained, when testing contrasting waters with different metal complexing ligands and when testing algae that produce metal complexing exudates. A change in metal speciation is indeed possible during the test because of algal exudates, as suggested by the change in dissolved $\mathrm{Cu}$ concentrations in the $+\mathrm{R}$ and not in the $-\mathrm{R}$ treatments (Table 1). Koukal et al. (2007) assessed the formation of exudates by algae. The amount of exudates formed after three days and an initial cell density of $10^{4}$ cells $\mathrm{mL}^{-1}$ was equivalent to $0.25 \mathrm{mg} \mathrm{DOC} \mathrm{L}^{-1}$. Grassi and Mingazzini (2001) showed that the exudates formed by Pseudokirchneriella subcapitata (Korschikov) Hindák 1990 are able to bind $\mathrm{Cd}^{2+}$. This technique can readily be 
applied to other metals. Chelex resin-buffered systems have been used with plants for $\mathrm{Cd}, \mathrm{Zn}$, Cu, Ni and Mn(Checkai et al., 1987; Degryse et al., 2007; Smolders and McLaughlin, 1996). The selectivity of Amberlite for binding $\mathrm{Cu}, \mathrm{Zn}$ and $\mathrm{Cd}$ is similar according to Demirbas et al. (2005). The selectivity for $\mathrm{Mn}$ is also similar to that of $\mathrm{Cd}$, according to our data (not published).

\section{Conclusion}

The resin-buffered solution adequately buffers the $\mathrm{Cd}^{2+}$ activity during algal growth and across different solution. The resin had no negative effect on algal growth. Cd uptake in algae was strikingly different between buffered and unbuffered systems and the Cd uptake in the buffered system was in line with the free ion activity model for metal uptake. The use of the resin can be advocated for metal bioavailability studies at low, but environmentally relevant, metal concentrations.

\section{Acknowledgments}

This research was funded by the Onderzoeksfonds K.U.Leuven under the project number OT/08/020. L. Verheyen thanks the Institute for the Promotion of Innovation through Science and Technology in Flanders (IWT-Vlaanderen).

\section{References}

Allen, H.E., Hall, R.H., Brisbin, T.D., 1980. Metal speciation. Effects on aquatic toxicity. Environ. Sci. Technol. 14, 441-443.

Anderson, M.A., Morel, F.M.M., Guillard, R.R.L., 1978. Growth limitation of a coastal diatom by low zinc ion activity. Nature. 276, 70-71.

Calow, P., 1998 (second edition). Handbook of ecotoxicology. Blackwell science Ltd. Cambridge. 
Chaney, R.L., 1988. Plants can utilize iron from Fe-N,N'-di-(2-hydroxybenzoyl-)ethylenediamine-N,N'-diacetic acid, a ferric chelate with $10^{6}$ greater formation constant than Fe-EDDHA. J Plant Nutr. 11, 1033-1050.

Checkai, R.T., Hendrickson, L.L, Corey, R.B., Helmke, P.A., 1987. A method for controlling the activities of free metal, hydrogen, and phosphate ions in hydroponic solutions using ion-exchange and chelating resins. Plant and soil. 99, 321-334.

Degryse, F., Verma, V.K., Smolders, E., 2007. Mobilization of Cu and Zn by root exudates of dicotyledonous plants in resin-buffered solutions and in soil. Plant and soil. 306, 69-84.

Demirbas, A., Pehlivan, E., Gode, F., Altun, T., Arslan, G., 2005. Adsorption of Cu(II), $\mathrm{Zn}(\mathrm{II}), \mathrm{Ni}(\mathrm{II}), \mathrm{Pb}(\mathrm{II})$, and $\mathrm{Cd}(\mathrm{II})$ from aqueous solution on Amberlite IR-120 synthetic resin. Journal of colloid and interface science. 282, 20-25.

Dizge, N., Keskinler, B., Barlas, H., 2009. Sorption from Ni(II) ions from aqueous solution by Lewatit cation-exchange resin. Journal of Hazardous Materials. 167, 915-926.

Environmental Protection Agency: EPA-600/9-78-018, 1978. The Selenastrum capricornutum Printz algal assay bottle test. Experimental design, application, and data Interpretation protocol. pp 38-50.

Errecalde, O., Seidl, M., Campbell, P.G.C., 1998. Influence of a low molecular weight metabolite (citrate) on the toxicity of cadmium and zinc to the unicellular green alga Pseudokirchneriella subcapitata: An exception to the free-ion model. Water Res. 32, 419429.

Florence, T.M., Stauber, J.L., 1986. Toxicity of copper-complexes to the marine diatom Nitzschia-Closterium. Aquatic Toxicology. 8, 11-26.

Franklin, N.M., Stauber, J.L., Apte, S.C., Lim, R.P., 2002. Effect of initial cell density on the bioavailability and toxicity of copper in microalgal bioassays. Environmental Toxicology \& Chemistry. 21, 742-751. 
Fortin, C., Campbell, P.G.C., 2000. Silver uptake by the green alga Chlamydomonas reinhardtii in relation to chemical speciation: influence of chloride. Environ. Toxicol. Chem. 19, 2769-2778.

Grassi, M., Mingazzini, M., 2001. ${ }^{113}$ Cd-NMR and fluoresence studies of the interactions between $\mathrm{Cd}(\mathrm{II})$ and extracellular organic matter released by Selenastrum capricornutum. Environ. Sci. Technol. 130, 4271-4276.

Holm, P.E., Christensen, T.H., Tjell, J.C., McGrath, S.P., 1995. Heavy metal in the environment: Speciation of cadmium and zinc with application to soil solutions. Journal of Environmental Quality. 24, 183-190.

Koukal, B., Rossé, P., Reinhardt, A., Ferrari, B., Wilkinson, K.J., Loizeau, J., Dominik, J., 2007. Effect of Pseudokirchneriella subcapitata (Chlorophyceae) exudates on metal toxicity and colloid aggregation. Water Res. 41, 63-70.

Lamelas, C., Pinheiro, J.P., Slaveykova, V.I., 2009. Effect of humic acid on Cd(II), Cu(II), and $\mathrm{Pb}(\mathrm{II})$ uptake by freshwater algae: kinetic and cell wall speciation considerations. Environ. Sci. Technol. 43, 730-735.

OECD 201, 2006. OECD guidelines for the testing of chemicals: Freshwater alga and Cyanobacteria, growth inhibition test.

Parker, D.R., Norvell, W.A., Chaney, R.L., 1995. GEOCHEM-PC a chemical speciation program for IBM and compatible personal computers. In Chemical equilibrium and reaction models; Loeppert, R.H., Schwab, A.P., Goldberg, S., Eds., SSSA special publication. 42: Madison, WI.

Phinney, J.T., Bruland, K.W., 1994. Uptake of lipophilic organic $\mathrm{Cu}, \mathrm{Cd}$ and $\mathrm{Pb}$ complexes in the coastal diatom Thalassiosira weissflogii. Environ. Sci. Technol. 28, 1781-1790.

Sigg, L., , Black, F., Cao, J., Cleven, R., Davison, W., Galceron, J., Gunkel, P., Kalis, E., Kistler, D., Martin, M., Noel, J., Nur, Y., Odzak, N., Puy, J., Van Riemsdijk, W., 
Smolders, E., McLaughlin, M.J.,1996. Chloride increases cadmium uptake in Swiss chard in a resin-buffered nutrient solution. Soil Sci. Soc. Am J. 60, 1443-1447.

Vigneault, B., Campbell, P.G.C., 2005. Uptake of cadmium by freshwater green algae: effects of pH and aquatic humic substances. J. Phycol. 41, 55-61.

Wilkinson, K.J., Buffle, J., 2004. Critical evaluation of physiochemical parameters and processes for modelling the biological uptake of trace metals in environmental (aquatic) systems. In Physicochemical kinetics and transport at biointerfaces. John Wiley \& Sons, Ltd. New Jersey. 


\section{Tables}

Table 1. Composition of the $\mathrm{NaNO}_{3}$ or $\mathrm{NaCl}$ nutrient solutions before (nominal) and after resin equilibration (measured). Means and standard deviations of measured samples $(n=8)$.

\begin{tabular}{|c|c|c|c|c|}
\hline \multirow[t]{2}{*}{ Element } & \multirow[t]{2}{*}{ units } & \multirow{2}{*}{$\begin{array}{l}\text { before resin } \\
\text { equilibration }\end{array}$} & \multicolumn{2}{|c|}{ after resin equilibration } \\
\hline & & & before inoculation & end of algal growth \\
\hline $\mathrm{Ca}$ & & 1 & $1.42(0.03)$ & $1.45(0.04)$ \\
\hline $\mathrm{K}$ & & 0.24 & $0.16(0.02)$ & $0.17(0.02)$ \\
\hline $\mathrm{Mg}$ & & 0.25 & $0.45(0.01)$ & $0.47(0.02)$ \\
\hline $\mathrm{Na}$ & 1010 & 42.5 & $40(0.2)$ & $39(0.1)$ \\
\hline $\mathrm{NO}_{3}$ & & 42 or 2 & n.m. & n.m. \\
\hline $\mathrm{Cl}$ & & 0.0023 or 40 & n.m. & n.m \\
\hline $\mathrm{PO}_{4}$ & & 20 & $19(0.5)$ & $10(1.5)$ \\
\hline $\mathrm{Fe}$ & $\mu \mathrm{M}$ & 15 & $14.7(0.4)$ & $15.6(0.6)$ \\
\hline B & & 3 & n.m. & n.m. \\
\hline Mo & & 30 & n.m. & n.m. \\
\hline Mn & & 300 & $<50$ & $<50$ \\
\hline $\mathrm{Cu}$ & $\mathrm{nM}$ & 100 & $6 *$ & $<50 / 120(36)^{* *}$ \\
\hline Co & & 62 & $<50$ & $<50$ \\
\hline $\mathrm{Zn}$ & & 100 & $6 *$ & $<50$ \\
\hline $\mathrm{Cd}$ & $\mathrm{kBq} \mathrm{L}^{-1}$ & 80 & $5(0.1)$ or $10.9(0.1)$ & See table 2 \\
\hline
\end{tabular}

n.m.: not measured; *: estimated. The $\mathrm{Zn}$ and $\mathrm{Cu}$ concentrations after resin equilibration were below detection limit $(<50 \mathrm{nM})$. Demirbas et al. (2005) found a similar selectivity of Amberlite for $\mathrm{Cu}, \mathrm{Zn}$ and $\mathrm{Cd}$ and the radioassay of $\mathrm{Cd}$ in solution allowed estimating the partitioning of $\mathrm{Cd}$, thereby, that of $\mathrm{Cu}$ and $\mathrm{Zn}$. **: The 
$\mathrm{Cu}$ concentration was below the detection limit of ICP-OES in the -R treatments. The concentration was $120 \mathrm{nM}$ in the $+\mathrm{R}$ treatments. 
Table 1: Cadmium speciation and Cd uptake by algae in solutions containing $40 \mathrm{mM}$ $\mathrm{NaNO}_{3}$ and $40 \mathrm{mM} \mathrm{NaCl}$ treatments, in presence (+R) or absence of Amberlite resin (-R). Means and standard deviations of $n=3$. Data illustrate that the $\mathrm{Cd}$ uptake by the algae was unaffected by solution composition in the $+\mathrm{R}$ treatment in line with the free ion activity model (FIAM) whereas greater $\mathrm{Cd}$ uptake in the $\mathrm{Cl}$ treatment was found in the $-\mathrm{R}$ treatment, violating the FIAM.

\begin{tabular}{|c|c|c|c|c|}
\hline & \multicolumn{2}{|c|}{ Solution only (-R) } & \multicolumn{2}{|c|}{ Resin-buffered solution $(+\mathrm{R})$} \\
\hline & $\mathrm{NO}_{3}$ treatment & $\mathrm{Cl}$ treatment & $\mathrm{NO}_{3}$ treatment & $\mathrm{Cl}$ treatment \\
\hline Free $\mathrm{Cd}^{2+}$ initial $\left(\mathrm{kBq} \mathrm{L}^{-1}\right)$ & $4.8(0.1)^{*}$ & $3.6(0.1)^{*}$ & $4.8(0.1)^{*}$ & $3.6(0.1)^{*}$ \\
\hline Total dissolved $\mathrm{Cd}$ initial $\left(\mathrm{kBq} \mathrm{L}^{-1}\right)$ & $5.0(0.1)$ & $10.9(0.1)$ & $5.0(0.1)$ & $10.9(0.1)$ \\
\hline Total dissolved Cd final $\left(\mathrm{kBq} \mathrm{L}^{-1}\right)$ & $2.1(0.1)$ & $5.4(0.5)$ & $5.6(0.5)$ & $11.9(0.5)$ \\
\hline $\mathrm{Cd}$ in washed algae $\left(\mathrm{mBq}\right.$ cell $\left.^{-1}\right)$ & $2.2(0.1)$ & $4.3(0.1)$ & $5.6(0.2)$ & $5.9(0.5)$ \\
\hline $\mathrm{Cd}$ in washed algae $\left(\mathrm{kBq} \mathrm{L}^{-1}\right)^{* *}$ & $2.9(0.1)$ & $6.0(0.1)$ & $7.5(0.3)$ & $8.5(0.7)$ \\
\hline Treatment effect & \multicolumn{2}{|c|}{$* * *$} & \multicolumn{2}{|c|}{ n.s. } \\
\hline
\end{tabular}

*: Predicted by Geochem, using initial composition

**: Cd concentrations in algal cell expressed per unit of solution volume 


\section{Figures}

Figure 1. Metal buffering kinetics in the resin-buffered abiotic solutions ( $\bigcirc$ : Amberlite, $\nabla:$ Chelex). Data show solution Cd concentrations in response to a complete renewal of the solution by a $\mathrm{Cd}$ free nutrient solution at $\mathrm{t}=0$, the solution was an unstirred solution and resin was located at the bottom of the container The curve is a first order rate model with a fitted time to $75 \%$ of equilibrium of less than $3 \mathrm{~h}$ for Amberlite and $18.5 \mathrm{~h}$ for Chelex. Standard deviations are given but are smaller than the symbols for some treatments, $n=3$.

Figure 2: The growth curves of the algae growing in a solution with $40 \mathrm{mM} \mathrm{NaNO}_{3}$ or 40 $\mathrm{mM} \mathrm{NaCl}$ in the presence (+R, open sysmbols) or absence (-R, closed symbols) of resin at the bottom of the growth beakers. Final cell densities were unaffected by any treatment $(\mathrm{p}>$ 0.05). Standard deviations are generally smaller than the symbols, $n=3$. $\bullet$ : unbuffered nitrate treatment, $\bigcirc$ : buffered nitrate treatment, $\mathbf{a}$ : unbuffered chloride treatment, $\square$ : buffered chloride treatment.

Figure 3: Total dissolved Cd concentration in solutions containing $40 \mathrm{mM} \mathrm{NaNO} 3$ (a) and $40 \mathrm{mM} \mathrm{NaCl}$ (b) treatments, in presence (+R) or absence of Amberlite resin (-R). Abiotic (Ab) controls are included. The uptake of Cd caused a lowering of the solution $\mathrm{Cd}$ in the absence of the resin whereas the resin maintained solution Cd by buffering. All solutions were equilibrated with the resin Amberlite before the start of the experiment and chlorocomplexation of $\mathrm{Cd}$ increased total dissolved $\mathrm{Cd}$ compared to nitrate treatments because of buffering of the free $\mathrm{Cd}^{2+}$ ion. Standard deviations are given but are smaller than the symbols for some treatments, $n=3$. 


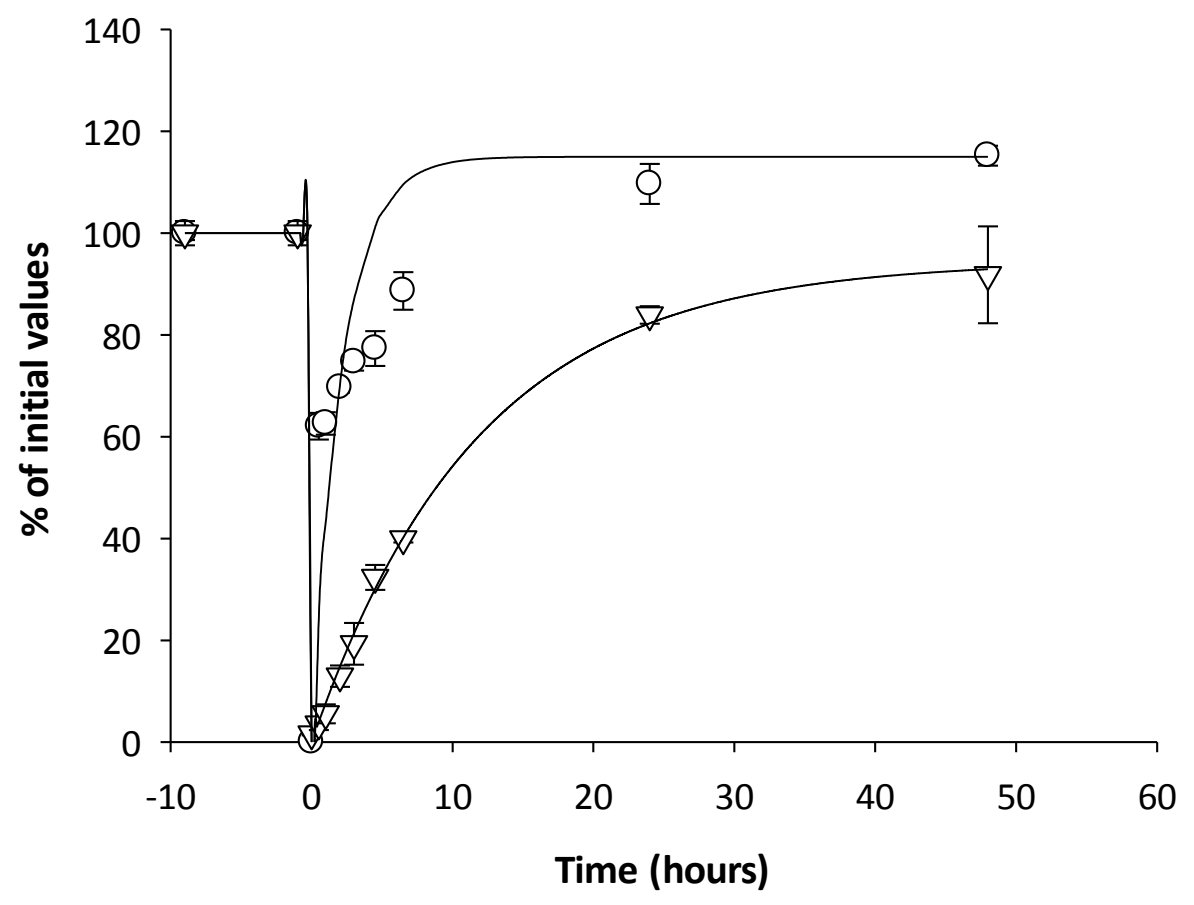

Figure 1 


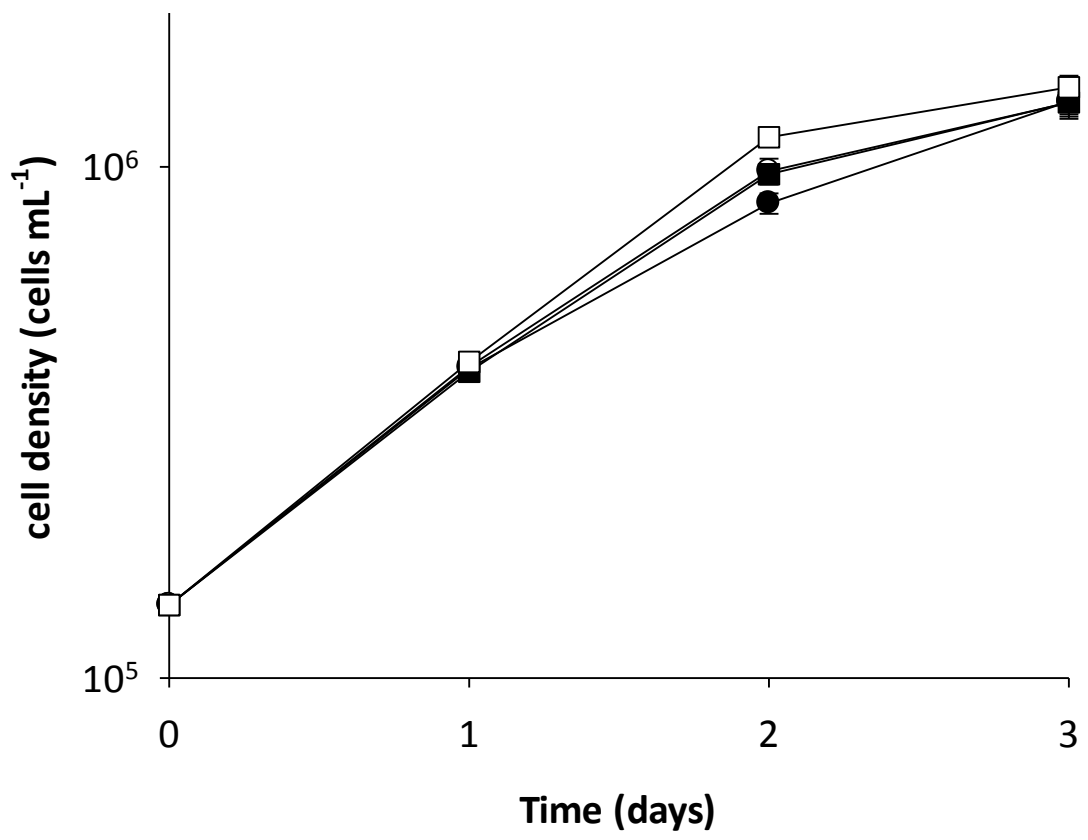

Figure 2 

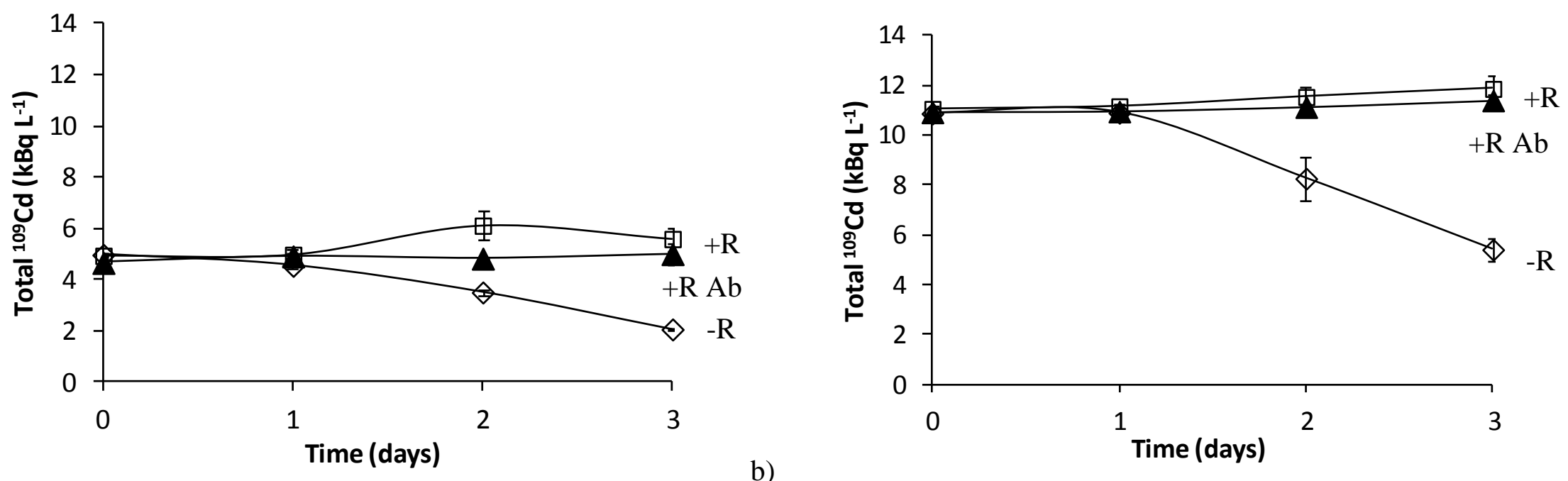

Figure 3 